\title{
Directors of Veterinary Services in the Anglo-Egyptian Sudan: Leonard Danels (Director, 16 December 1922-19 June 1924), 1913-1924
}

\author{
R Trevor Wilson* \\ Bartridge Partners, Bartridge House, Umberleigh, North Devon, UK
}

\begin{abstract}
Leonard Danels was born in London in 1884 and lived his early life there in the household of his parents. He was admitted as a Member of the Royal College of Veterinary Surgeons (MRCVS) in 1905 and was commissioned as a Lieutenant in the Army Veterinary Services in August 1905. He was stationed in Aldershot until the end of 1908 when he was posted to India and promoted to Captain in August 1910 . He was stationed at Tidworth, for a short period in 1912 and 1913 before being seconded to the Egyptian Army in June of the latter year. He served in Mongalla in the south of Sudan in 1914. On home leave in August 1914 he was immediately retransferred to the British Army and landed in France on 15 August. Retransferred to the Egyptian Army in August 1915 he served as Veterinary Inspector in various parts of Sudan until he was appointed Assistant Director of Veterinary Services in Khartoum. Promoted to Director in November 1922 he served in that position until June 1924. Danels was restored to the establishment of the British Army after leaving Sudan in 1924, was eventually promoted to Major and then to Brevet Lieutenant Colonel. In 1928 Major Danels married, at the age of 44, a spinster of about his own age. He was appointed Assistant Director General of the Army Veterinary Services in 1930. The marriage and the high post in the veterinary services were not to last long as Danels died in the Millbank Military Hospital on 10 July 1932 aged47.
\end{abstract}

\section{Introduction}

A fanatical religious zealot claiming to be the Mahdi (the "Guided One") raised a rebellion of the Sudanese people against the Egyptians who were governing the country in the 1880s. A British Major General, Charles "Chinese" Gordon (himself something of a fanatic) was sent to assist the Egyptians but became besieged in Khartoum. A British relief force fought its way up the River Nile in 1884/1885 but Gordon was killed in the Governor-General's palace in Khartoum just two days before it arrived. A second expedition was mounted in the mid-1890s to "reconquer" Sudan. A major victory by British and Egyptian troops over the Sudanese under the Khalifa ("Successor" the Mahdi had died shortly after the death of Gordon) at the Battle of Omdurman in September 1898 resulted in the country once again becoming under foreign rule. An essentially British enterprise, the Anglo-Egyptian Sudan, nominally a joint administration of the two countries, was established as a Condominium shortly afterwards $[1,2]$. A large military presence, mostly Egyptian but supported by British troops and administrators, struggled to maintain law and order in the face of continuing unrest and civil disturbance by the Sudanese peoples. This necessitated the use of enormous numbers of cavalry and transport animals (horses, mules, donkeys and camels) to govern and control the turbulent population. The health of these animals was the major consideration in the setting up of a fledgling veterinary service. In all, 12 people served as Principal Veterinary Officers (to 1910) or as Directors of Veterinary Services (from 1910 to 1956 ) in the 55-year period from the inception of the Anglo-Egyptian Sudan in 1901 to the achievement of independence by the Republic of Sudan on 1 January 1956. During the early years the veterinarians were military officers who were seconded, usually for short periods, from the British to the Egyptian Army which in turn employed them directly or seconded them to the Sudan. Leonard Danels was the sixth of the twelve expatriate personnel who served as head of the Sudan Veterinary Service, being in the post from 1922 to 1924.

\section{Early Life, 1884-1905}

Leonard Danels was born on 8 August 1884 at Turnham Green, Chiswick in West London [3]. He was the first child of Richard George Danels and Clara Plowman and was baptized in Christ Church, Turnham Green on 2 November (Figure 1).

Aged six years at the census of 1891, Leonard was living with his parents at Number 1a Upper Berkeley Street in London. His father, who had been described as a Traveller on the baptismal entry of Leonard in 1884, was a Licensed Victualler [4]. Also living in the household were Leonard's mother, two younger female siblings, two barmaids, a general servant and a nurse. Leonard was not living with his parents at the time of the 1901 census and has not been found elsewhere in it.

In 1905 Leonard Danels graduated from Royal Veterinary College, London with the degree of Bachelor of Veterinary Medicine (B Vet Med) and became a Member of the Royal College of Veterinary Surgeons (MRCVS) on 8 August [5]. He was commissioned as a Lieutenant in the Army Veterinary Department on 26th August and was posted to Aldershot [6,7]:

${ }^{*}$ Correspondence to: $\mathrm{R}$ Trevor Wilson, Bartridge Partners, Bartridge House, Umberleigh, North Devon, UK, E-mail: trevorbart@aol.com

Key words: royal army veterinary corps, first world war, India, campaign medals, transport animals, animal diseases

Received: March 01 2019; Accepted: March 08, 2019; Published: March 11, 2019 

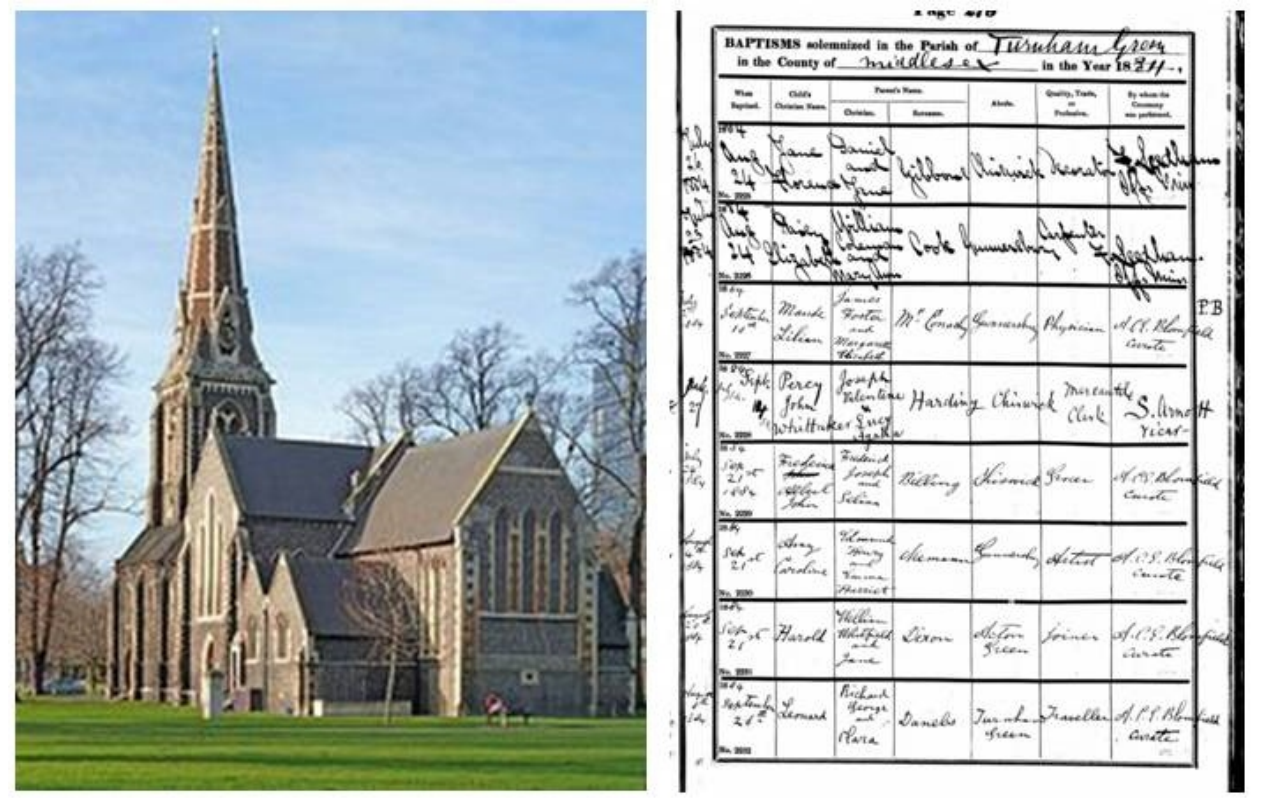

Figure 1. Christchurch Anglican church, Turnham Green and baptism register entry for Leonard Danels

ARMY VETERINARY DEPARTMENT.

The undermentioned Gentlemen to be Lieutenants.

Dated 26th August 1905:-

Leonard Danels, vice R. J. Collings, resigned.

\section{Early days in the Army Veterinary Service, 1906-1913}

Throughout 1906, 1907 and 1908 Lieutenant Danels was based at Aldershot [8-10]. At Aldershot he may have worked at the Army Veterinary Corps No 1 Veterinary Hospital which was staffed by No 1 and No 2 Sections of the AVC or he may have been seconded directly to a cavalry regiment. Posted to India in 1909 he served at Muthra (now Mathura) in 1909 [11] in the northeast of the country in what is now Uttar Pradesh State and the reputed birthplace of the Hindu God Krishna. He was later transferred to Meerut to the north of Mathura and best known for its being the starting place of the Indian Mutiny [12]. Whilst at Mathura he was promoted to Captain on 26 August 1910, having completed the statutory five years service as a Lieutenant [13]:

\section{ARMY VETERINARY SERVICE. - . ... .;}

Army Veterinary Corps;

The undermentioned Lieutenants to be Captains. Dated 26th August 1910: -

Leonard Danels.

Captain Leonard Danels continued to serve at Meerut through 1911 [14] and into 1912 [15]. In 1911 he was presented with the Delhi Durbar 1911 Medal on the recommendation of the Adjutant General in India [16]. ${ }^{1}$ This was the first of several medals garnered by Danels but the only one of a "commemorative" nature (Figure 2). Danels left India towards the end of 1912 and was posted to Tidworth, a large

1. A durbar was a ceremonial assembly held by the British Raj (that is, The Government of India) to celebrate the crowning of an Empress or Emperor of India. Thousands of people were involved including most Indian Princes and nobleman who paid homage to the British Royals and who in turn were treated to fantastic displays. The 1911 Delhi Durbar was the last to be held and the only one attended by the British Monarch (aka The Emperor of India). The 1911 silver commemorative medal was issued to 27,000 officers and men of the British Army in India and of the Indian Army and about 160 gold medals were presented to high officials and Indian princes. military establishment in Wiltshire, where he served for a part of 1913 [17].

\section{Sudan and World War I, 1913-1924}

In mid-1913 Captain Leonard Danels was seconded to the Egyptian Army [18]:

\section{War Office,}

25th July 1913.

REGULAR ARMY

ARMY VETERINARY SERVICE.

Army Veterinary Corps,

Captain Leonard Danels is seconded for service with the Egyptian Army. Dated 20th June 1913.

Captain Danels sailed from London on 20 June 1913 bound for Port Said travelling First Class in the SS Egypt with onward destination being Sudan [19]. On arrival in Sudan he was granted the local rank of Bimbashi and first served as a Veterinary Inspector in Mongalla Province in the south of the country (Table 1$)^{2}$.

Danels was on leave in the United Kingdom at the outbreak of World War I on 5 August 1914. He was immediately retransferred to the British Army as noted shortly afterwards by the Sudanese authorities "L. Danels (Veterinary Department) retransferred to Army, 6/8/14" [21] but it was not until six years later that this was officially announced in the London Gazette [22]:

\section{ARMY VETERINARY SERVICE.}

R.A.V.C.-The undermentioned are restd. to the estabt.: -

5th Aug. 1914.

Capt. L.Danels

Danels disembarked in France on 14 August 1914 and was clearly soon involved in or near the front line as, in a list of several thousand men and women from all branches of the armed forces he received a Mention in Despatches [23]

2. Bimbashi was an Egyptian Army rank equivalent to a British Major: officers seconded from Britain to Egypt were invariably given local ranks more senior than their British substantive ones. 

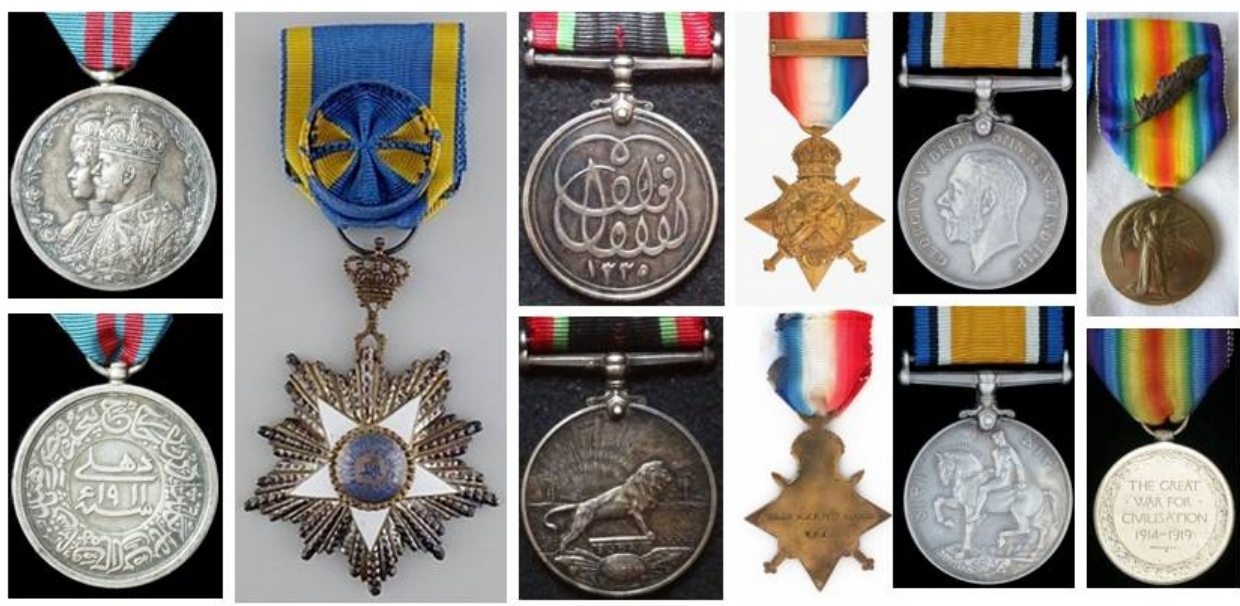

Figure 2. Commemorative and campaign medals of Leonard Danels (left to right: Delhi Durbar 1911 Commemorative Medal; Egyptin Order of the Nile Fourth Class breast badge; Khedive's Sudan Medal 1910 (Danels' medal would have Clasp for "Nyima 1917-18"); 1914 Star with Clasp for actually being under enemy fire; War Medal; Allied Victory Medal Oak Leaves for being Mentioned in Despatches)

Table 1. Outline of the career of Leonard Danels in Sudan, 1913-1924

\begin{tabular}{|c|c|c|c|c|}
\hline Date & Appointment & Rank and name & Location & Notes \\
\hline 20 June 1913 & & & & Sailed from London \\
\hline 1 March 1914 & Veterinary Inspector & El Bimbashi L Danels & Mongalla Province & \\
\hline 1 July 1914 & & El Bimbashi L Danels & & Leave \\
\hline 5 August 1914 & Retransferred to British Army & & & Landed France 14 August \\
\hline 6 August 1915 & Seconded to Egyptian Army & & & \\
\hline 1 January 1916 & Veterinary Inspector & El Bimbashi L Danels & Khartoum & \\
\hline 1 November 1916 & Veterinary Inspector & El Bimbashi L Danels & Halfa & \\
\hline 1 January 1918 & Veterinary Inspector & El Kaimakan L Danels Bey 4 Nile & Kordofan Province & \\
\hline 1 January 1919 & Assistant Director & El Kaimakan L Danels Bey 4 Nile & Khartoum & \\
\hline 1 April 1920 & Assistant Director & El Kaimakan L Danels Bey 4 Nile & Khartoum & For leave \\
\hline 1 April 1923 & Director & $\begin{array}{l}\text { (Lieutenant Colonel) El Miralai L } \\
\text { Danels Bey } 4 \text { Nile }\end{array}$ & Khartoum & \\
\hline 1 April 1924 & Director & $\begin{array}{l}\text { (Lieutenant Colonel) El Miralai L } \\
\text { Danels Bey } 4 \text { Nile }\end{array}$ & Khartoum & Due from leave 19 June 1924 \\
\hline 19 June 1924 & & & & Departed Sudan \\
\hline
\end{tabular}

Source: [20]

\section{War Office,}

17th February, 1915.

The following despatch has been received by the Secretary of State for War from the Field-Marshal Commanding-in-Chief, British Forces in the Field: -

14th January, 1915.

MY LORD,-

In accordance with the last paragraph, of my Despatch of the 20th November, 1914, I lave the honour to bring to notice names of those whom I recommend for gallant and distinguished service in the field.

I have the honour to be,

Your Lordship's most obedient Servant,

J. D. P. FRENCH,

Field-Marshal, Commanding-in-chief, The British Army in the Field.

ARMY VETERINARY CORPS

Danels, Captain L.

His retransfer to the British Army was not, however, a long term one and he was again seconded to the Egyptian Army and went back to Sudan on 6 August 1915 (although once again officialdom was extremely tardy, and the transfer did not appear in the London Gazette until 1920) [24]:

\section{War Office,}

20th July 1920

REGULAR FORCES

ARMY VETERINARY SERVICE.

R.A.V.C.-The undermentioned are secd, for service with the Egyptian Army: -

Capt (now temp. Maj.) L. Danels. 6th Aug. 1915.
At the beginning of 1916 Bimbashi L Danels was a Veterinary Inspector based in Khartoum (Table 1). He served in Darfur probably during April and May 1916 and was again Mentioned in Despatches [25]:

\section{War Office,}

25th October, 1916

The following Despatch has been received by the Secretary of State for War from Genera Sir Reginald Wingate, G.C.B., Sirdar and Governor-General of the Sudan: -

Khartoum

8th August, 1916.

SIR, - I have the honour to forward for the information of the Secretary of State for War my Despatch on the military operations in Darfur, together with a brief report on the services of the Egyptian Army and the Sudan Administration since the outbreak of war in Europe.

Finally, I have the honour to append a list of names of officers, officials and others whose work in connection with military operations and the situation in the Sudan created by the war is deserving of special notice and commendation.

I have the honour to be,

Sir,

Your Obedient Servant,

REGINALD WINGATE, General,

Sirdar and Governor-General of the Sudan.

No. 1

DARFUR OPERATIONS.

Staff and Administrative Services.

Danels, Capt. L., Army Veterinary Corps. 
Later in 1916 Danels had been transferred to Halfa (Table 1) in the extreme north of Sudan on the Egyptian border. The importance of Sudan's livestock trade was very apparent during the war. Several thousand cattle had been sent to Malta early in the war, but further trade was halted following the discovery of contagious pleuro-pneumonia in one consignment. The Egyptian market was very important as not only were other sources of supply to the Egyptian civilian market greatly curtailed but also the considerable military forces there could consume as much meat as could be sent from the Sudan. Trade boomed but when 37000 cattle and 180000 sheep were exported in 1918 the railway infrastructure and rolling stock was operating at or even in excess of full capacity. Ceaseless care was necessary in order to prevent pleuro-pneumonia, and rinderpest, from infecting export cattle and several quarantine stations were established along the stock routes and at the border points [26,27]. It is probable that Danels' main duties when stationed at Halfa were to ensure free and easy passage of diseasefree stock from Sudan to Egypt. Remounts for Palestine were also an important activity and the Veterinary Department bought several thousand horses and mules for that theatre of operations. In conjunction with this greater efforts were made to improve the native horses which were undersized and of bad conformation. In 1915 the Department had four stallions at stud and Horse Shows were held in different parts of the country in order to encourage and interest the people [28].

Towards the end of 1917 the services of Captain Danels were recognized by the Sultan of Egypt via the award of the Order of the Nile, Fourth Class (Figure 2) [29]:

Whitehall, August 29, 1917.

The KING has been, pleased to give and grant unto the undermentioned gentlemen His Majesty's Royal licence and authority to wear Decorations (as stated against their respective names) which have been conferred upon them by His Highness the Sultan of Egypt in recognition of valuable services rendered by them: -

Fourth, Class of the Order of the Nile.

Captain Leonard Danels Army Veterinary Corps, Sudan Government Service) ${ }^{3}$

It was perhaps this recognition that led to his accelerated promotion in the Egyptian Army to the rank of Kaimakan (equivalent to a Lieutenant Colonel in the British Army) and the granting of an honorary title "Bey" whilst still a substantive Captain and whilst still a Veterinary Inspector serving in Kordofan (Table 1). At about this time he also gained the Khedive's Sudan Medal 1910 Medal (Figure 2) with the Clasp "Nyima 1917-18" which was awarded to 47 British officers under Special Army Order dated 22 January 1919 [30] ${ }^{4}$. The Nyima Clasp was awarded to personnel who took part in a series of "punitive" raids against the Nuba people of southwest Kordofan in late 1917 and early 1918. The British administration of this time considered

3. The Order established in 1915 by Sultan Hussein Kamel of Egypt was awarded for rendering useful service to the country. Ranking beneath the Order of Ismail, it was awarded to distinguished Egyptian citizens and often to British officers and officials serving in Egypt. The order comprised five classes:

Grand Cordon (First Class): Badge worn from a sash over the right shoulder with a star on the left chest.

Grand Officer (Second Class): Badge worn around the neck with a smaller star on the left chest.

Commander (Third Class): Badge worn around the neck.

Officer (Fourth Class): Badge worn on the left chest from a ribbon bearing a rosette.

Knight (Fifth Class): Badge worn on the left chest from a plain ribbon.

Directors of the Sudan Veterinary Services received this award in either Third or Fourth Classes.

4. Captain Robert Starmer Audas was also a recipient of the Nyima Clasp [28]. It is not clear why Danels was not awarded the medal with Clasp "Nyala 1916" when he appears to have been present at that period and was indeed Mentioned in Despatches. the Nuba to be a troublesome, uncivilized and primitive group of people who could only be brought into the modern Sudan by being shown, on a regular basis and on the slightest excuse, the power of the Administration [31].

Towards the middle of 1918, probably as a result of his being named Assistant Director of Sudan Veterinary Services, Captain Danels was promoted to Temporary Major in the British Army [32]:

\section{Memoranda,}

The undermentioned to be temp. Majs.: -

Capt. L. Danels, R.A.V.C., for service with the, Egyptian Army, 1st July 1918.

The Wandsworth Electoral Registers for 1918 [33] and 1919 [34] have Leonard Danels listed at 20 Westwell Road, Wandsworth, London SW 16 (Figure 3). He was listed as being in Division II which comprised Naval or Military Personnel registered as "absent" voters (he was, of course, Assistant Director of Veterinary Services in Sudan at the time) and qualified to vote in Parliamentary but not Local Government elections. Richard George Danels, the father was listed in Division I at the same address. Leonard was again registered at 20 Westwell Road in 1928 [35] and 1929 [36] as an absent naval and military voter when the house was also occupied by his father and three spinster sisters ${ }^{5}$.

Promoted to Assistant Director in 1918, El Kaimakan L Danels Bey, Nile 4th Class served in Khartoum until he became Director on 16 December 1922 when he was also promoted to the Egyptian rank of Miralai (British equivalent Colonel) and also made a Temporary Liutenat Colonel in the British Army on the same date [37]:

\section{War Office,}

23rd February 1923.

REGULAR FORCES.

Memoranda

The undermentioned to be temp. Lt.-Cols. for service with the Egyptian Army: -

Maj. L. Danels, R.A.V.C. 16th Dec. 1922.

In the meantime, on 15 December 1920, he was informed that he was entitled to the campaign medals associated with service in World War 1, these being the 1914 Star with Clasp for service under fire between 5 August and 22 November 1914, the War Medal and the Allied Victory Medal with Oak Leaves for Mentions in Despatches (Figure 4) [38,39].

A Principal Veterinary Officer with the rank of Miralei in the Egyptian Army, Temporary Lieutenant Colonel Leonard Danels was Director of Sudan Veterinary Services from 16 December 1922 to 19 June 1924. He Inherited a "flourishing department" from Major Tapley $[26,40]$. Prior to that, in 1913 , the veterinary services had been organized into four Sections: Survey, General, Quarantine and Animal. The Survey Section had been unable to obtain a bacteriologist and for its first years had confined itself to routine diagnostic work. Captain Richard Hall Knowles was recruited as Veterinary Bacteriologist on 28 August 1922. It was obvious that if a healthy livestock industry were to be established, adequate research and laboratory facilities must be provided. With the limited funds at his disposal Knowles began organising a library, replacing equipment and erecting buildings. Rinderpest, Contagious Bovine Pleuro-Pneumonia (CBPP) and camel trypanosomosis were the most urgent problems and, supported by Danels, Knowles lost no time in tackling them. He did some "real" research in attempts to produce a vaccine against CBPP, "Naganol", which had recently come on the market as a curative for camel trypanosomosis was tested and

5. 20 Westwell Road seems to have been a family property as Leonard's father was registered there in 1899: none of his wife nor daughters was registered at that time but of course they would not be as women did not have the vote at that time. 


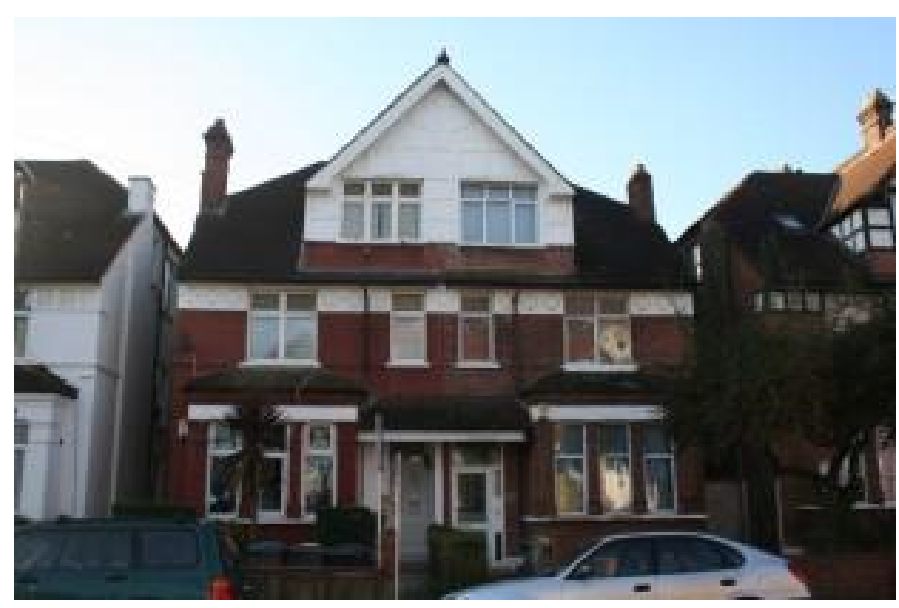

Figure 3. The long-term home of the Danels family at Number 20 Westwell Road, Wandsworth



Figure 4. Medal Index Card of Leonard Danels showing various annotations

the possibility of local manufacture of anti-rinderpest serum in order to avoid having to import it from Eritrea or Egypt was tested. Camels were, however, still a major means of transport and trypanosomosis was their principal health problem. Three of the four papers Knowles produced in the Journal of Comparative Pathology and Therapeutics during his tenure until 1927 were on this topic with the fourth relating to immunization against CBPP. Thus, during the tenure of Danels as Director, considerable progress was made in identifying, controlling and curing some major animal health problems.
Danels left Sudan on 19 June 1924 (Table 1) after 11 years of service with the Egyptian Army except for one year in the European theatre at the beginning of World War I. Except for a short period as Acting Director by Major Harry Bone in 1924, Danels was the last military veterinarian to serve as Director consequent on a decision by the British War Office to no longer second military veterinary officers to the Egyptian Army. This was not, however, the end of military vets in Sudan as several then serving officers chose to transfer to the Sudan Government. Danels departure from Sudan did not signify the end of his military career but did have a temporary negative effect on it as his rank as Temporary Lieutenant Colonel was withdrawn, and he was again reduced to major [41]:

\section{Memoranda}

Maj. (temp. Lt.-. Col.) L. Danels,

R.A.V.C., relinquishes his temp, rank on ceasing to be empld. with the Egn. Army. 20th June 1924

\section{After Sudan, 1924-1932}

On cessation of his employment by the Egyptian Army, it was only a short time later that Major Danels was restored to the establishment of the British Army [42]

\section{War Office,}

30th September 1924

REGULAR FORCES

ROYAL ARMY VETERINARY CORPS.

Maj. L. Danels is restd. to the estabt. 12th Sept. 1924.

At the beginning of 1928 Leonard Danels married Grace Gertrude Hopkins [43]. He was 44 years old and she, aged 31, was 13 years his junior. During 1929 and 1930 the couple lived at 16a Mordern Road, Greenwich (Figure 5). According to the Electoral Register for Greenwich he was entitled to vote in Local Elections through an occupational (that is, occupying a property and not work related) qualification as was Grace through her husband's qualification. Leonard was not, however, entitled to vote in a Parliamentary Election although Grace was through a residential qualification [44].

In the spring of 1930 Leonard Danels was appointed to the position of Assistant Director General of the Army Veterinary Services while still only a Major [45] and it was not until two years later that he was promoted to Brevet Lieutenant Colonel [46].

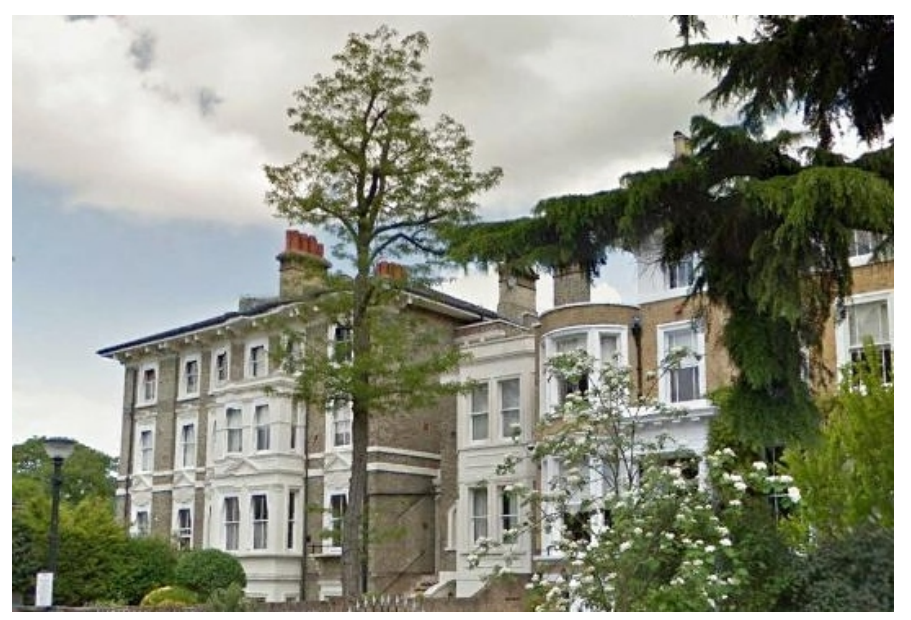

Figure 5. Number 16 Mordern Road, Greenwich: Leonard Danels and his wife lived in a flat in ths house (Number 16a) in the early 1930s 


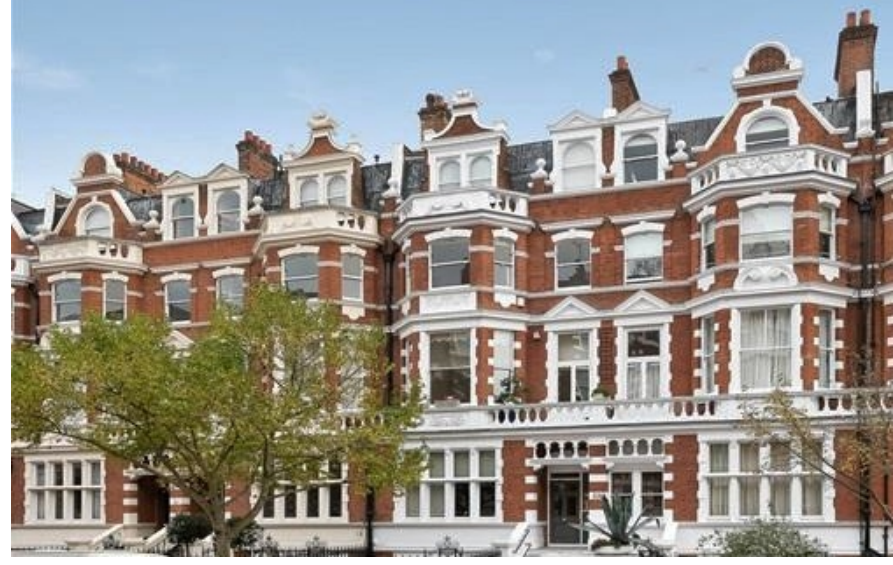

Figure 6. Number 23 Bolton Gardens, South Kensington, a flat here was the home of Leonard Danels at the time of his death in 1932

\section{War Office,}

25th April 1930.

REGULAR ARMY

COMMANDS AND STAFF.

The undermentioned appts. are made: -

Maj. L. Danels, R.A.V.C., to be Asst. Dir.-Gen., A. Vet. Servs., War Office. 15th Apr. 1930.

\section{War Office Halfyearly Brevets}

To be Bt. Lt.-Cols.

Maj. L. Danels, R.A.V.C.

Neither the appointment nor the promotion was destined to last long. Leonard Danels of 23 Bolton Gardens, South Kensington (Figure 6) died aged 47 on 10 July 1932 at Millbank Military Hospital Westminster [47]. Probate of his effects to the value of $£ 817313 \mathrm{~s} 1 \mathrm{~d}$ was granted to his widow Grace Gertrude Danels on 7 September [48]. Grace never married again although she lived on for another 52 years and died aged 87 on 1 March 1984.

\section{References}

1. Churchill WS (1899) The River War. Eyre and Spottiswoode Ltd, London.

2. Colville HE (1889) History of the Sudan Campaign. Her Majesty's Stationery Office, London.

3. GRO (1884) England and Wales Civil Registration Indexes: Brentford, 3a 119. General Register Office, London.

4. National Archives (1891) Census Returns of England and Wales, 1891; Class: RG12; Piece: 96; Folio: 34; Page: 14. National Archives of the UK, Kew.

5. Clare Boulton (2017) RCVS Knowledge, Personal Communication.

6. Hart HG (1908) The New Annual Army List, Militia List, and Yeomanry Cavalry List, for 1908. John Murray, London.

7. London Gazette (1905) https://www.thegazette.co.uk/London/issue/27830/page/5844/ data.pdf. 25 August 1905.

8. Hart HG (1906) The New Annual Army List, Militia List, and Yeomanry Cavalry List, for 1906. John Murray, London.

9. Hart HG (1907) The New Annual Army List, Militia List, and Yeomanry Cavalry List, for 1907. John Murray, London.

10. Hart HG (1908) The New Annual Army List, Militia List, and Yeomanry Cavalry List, for 1908. John Murray, London.

11. Hart HG (1909) The New Annual Army List, Militia List, and Yeomanry Cavalry List, for 1909. John Murray, London.

12. Hart HG (1910) The New Annual Army List, Militia List, and Yeomanry Cavalry List, for 1910. John Murray, London.

13. London Gazette (1910) https://www.thegazette.co.uk/London/issue/28410/page/6183. 26 August 1910 .
14. Hart HG (1911) The New Annual Army List, Militia List, and Yeomanry Cavalry List, for 1911. John Murray, London.

15. Hart HG (1912) The New Annual Army List, Militia List, and Yeomanry Cavalry List for 1912. John Murray, London.

16. https://www.forces-war-records.co.uk/namesearch/?FirstName=Leonard\&Surname=D anels\&RecordType=NotSelected\&RecordDateStartYear=1700\&RecordDateEndYear $=$ 2019\&CollectionList $=177 \&$ Step $=1$.

17. Hart HG (1913) The New Annual Army List, Militia List, and Yeomanry Cavalry List, for 1913. John Murray, London.

18. London Gazette (1913) https://www.thegazette.co.uk/London/issue/28740/page/5324 25 July 1913

19. National Archives (1913) Board of Trade: Commercial and Statistical Department and successors: Outward Passenger Lists.; Class: BT27. National Archives of the UK, Kew.

20. Sudan Government (1914) Monthly return of senior officials, Sudan government, and British officers temporarily employed in Sudan government service, showing appointments \& stations on 1 January 1914 and probable moves during the month [ and other monthly and quarterly returns in same series].

21. Sudan Government (1914) Sudan Gazette, No. 267, 28 November 1914. Sudan Government, Khartoum.

22. London Gazette (1920) https://www.thegazette.co.uk/London/issue/31902/supplement/5573. 14 May 1920.

23. London Gazette (1915) https://www.thegazette.co.uk/London/issue/29072/supplement/1672. 16 February 1915.

24. London Gazette (1920) https://www.thegazette.co.uk/London/issue/31987/supplement/7730. 20 July 1920.

25. London Gazette (1916) https://www.thegazette.co.uk/London/issue/29800/supplement/10375. 25 October 1916

26. Jack JDM (1961) Part V The Sudan. In: West JP (ed) A History of the Overseas Veterinary Services Part One. British Veterinary Association, London, 123-143.

27. Tvedt T (1983) Colonial Technicians: The Sudan Veterinary Service 1898-1956. Thesis. University of Bergen, Bergen, Norway.

28. Wilson RT (2018) Directors of Veterinary Services in the Anglo-Egyptian Sudan: Robert Starmer Audas (Assistant Director, 1925-1932) 1909-1935. Intern J Vet and Ani Med 1: 109.

29. London Gazette (1917) https://www.thegazette.co.uk/London/issue/30261/page/9030. 31 August 1917. AND Edinburgh (Gazette 1917) https://www.thegazette.co.uk/Edinburgh/issue/13138/page/1894/data.pdf. 4 September 1917.

30. HMSO (1919) Quarterly Army List 1919 Fourth Quarter Part 2. His Majesty's Stationery Office, London.

31. Willis J (2003) Violence, authority, and the state in the Nuba Mountains of Condominium Sudan. Historical Journal 46: 89-114.

32. London Gazette (1919) https://www.thegazette.co.uk/London/issue/31298/supplement/4999. 1April 1919.

33. LMA (1918) Electoral Register, Wandsworth, 1918. London Metropolitan Archives, London.

34. LMA (1919) Electoral Register, Wandsworth, 1919. London Metropolitan Archives, London.

35. LMA (1928) Electoral Register, Wandsworth, 1928. London Metropolitan Archives, London.

36. LMA (1929) Electoral Register, Wandsworth, 1929. London Metropolitan Archives, London

37. LMA (1899) Electoral Register, Wandsworth, 1899. London Metropolitan Archives, London.

38. London Gazette (1923) https://www.thegazette.co.uk/London/issue/32798/page/1303. 23 February 1923.

39. National Archives (1920) BW \& V. Medals; RAVC WO329, Piece 2292. National Archives of the UK, Kew.

40. Wilson RT and Knesl O (2018) Directors of Veterinary Services in the Anglo-Egyptian Sudan: James John Bonifant Tapley, 1917-1922. Intern J Vet Ani Med 1: 113. 
41. London Gazette (1924) https://www.thegazette.co.uk/London/issue/32948/page/4808. 20 June 1924.

42. London Gazette (1924) https://www.thegazette.co.uk/London/issue/32978/page/7115. 30 September 1924.

43. GRO (1928) England and Wales Civil Registration Indexes: Brentford Jan-Feb-Mar 1928 3a 220. General Register Office, London.

44. LMA (1930) Electoral Register, Greenwich, 1930. London Metropolitan Archives, London.
45. London Gazette (1930) https://www.thegazette.co.uk/London/issue/33600/page/2596. 2 April 1930.

46. London Gazette (1932) https://www.thegazette.co.uk/London/issue/33786/page/49. 1 January 1932 .

47. GRO (1932) England and Wales Civil Registration Indexes: St George Hanover Square Jul-Aug-Sep 1932 1a 437.

48. PPR (1932) Calendar of the Grants of Probate and Letters of Administration made in the Probate Registries of the High Court of Justice in England. London, England. Principal Probate Registry, London.

Copyright: (C2019 Wilson RT. This is an open-access article distributed under the terms of the Creative Commons Attribution License, which permits unrestricted use, distribution, and reproduction in any medium, provided the original author and source are credited. 